\title{
The Interaction of Egyptian and Aramaic Literature
}

\author{
JOACHIM FRIEDRICH QUACK \\ Institute of Egyptology-University of Heidelberg
}

While there has been considerable discussion on the question of Egyptian influence on Old Testament literature, especially wisdom texts such as the Teaching of Amenemope (Humbert 1929; Bruyce 1979; Römheld 1989; Laisney 2007) and Canticles (e.g., Fox 1985), the relation between nonbiblical Jewish literature and Egyptian compositions has been much less in the focus. The relevant compositions I intend to discuss are written in Aramaic, and this entails the methodological problem to which extent they can be classified as "Jewish"-or Jehudite-literature and thus legitimately be brought into the scope of this volume. I can point out that at least Ahiqar is archaeologically ascertained to come from the group on Elephantine Island that stylized itself as "Jews." Obviously, this will lead to the wider question of what it meant to be a "Jew" during the Achaemenid period.

As a point of comparison, Egyptian literary texts of the Late period will be used. I restrict myself to those written in the vernacular demotic language because there is no evidence that literary texts in classical Middle Egyptian language were created anew during the Late period. As a matter of fact, they even seem to have died out during that period; there is no single manuscript of a Middle Egyptian literary composition later than the Saïtic period (26th Dynasty; Quack 2003a). This restriction still leaves us with a fairly large Egyptian corpus (Quack 2005a).

In order to use this corpus to the full, we have to keep in mind the chronological question. At first, it seems appropriate to limit ourselves to cases of Egyptian texts from the Achaemenid period, in keeping with the focus of this volume. However, with a closer look, this raises an important methodological issue: what exactly is an Egyptian text from the Achaemenid period? Many Egyptologists tend to base their text chronology mainly on actual attestations of manuscripts. Thus, while avoiding the pitfall of fanciful early dating that has sometimes plagued Egyptology, they incur the even greater risk of mistaking the random preservation for a structure of development (von Lieven 2007: 
223-54). Specifically for the demotic literature, we have to reckon with the fact that there are hardly any preserved demotic literary manuscripts from the Persian period actually known nowadays. ${ }^{1}$ By far, the greatest number of demotic literary fragments date from the Roman period. However, in many cases there are inherent arguments for attributing the original date of composition to pre-Ptolemaic times. ${ }^{2}$ Thus, I feel justified in using compositions whose actual manuscripts are post-Achaemenid as long as there are good reasons for connecting them with Imperial Aramaic texts.

The best-known case of a translation from Aramaic to Egyptian is the Story and Wisdom of Ahiqar. Set at the Neo-Assyrian court and thought by several scholars actually to reflect Assyrian court milieu (Fales 1994; Koch-Westenholz 1995: 63; Dalley 2001: 153-54; Parpola 2005; Weigl 2010: 691-703), the oldest preserved manuscript, written in Imperial Aramaic, was found at Elephantine and dates from the 5th century B.C.E. ${ }^{3}$ It has been long known that this composition was, besides renderings in many other languages, ${ }^{4}$ also translated into demotic Egyptian. ${ }^{5} \mathrm{Up}$ to now, only two demotic Egyptian fragments of the narrative frame (manuscripts dating from the Roman imperial period) have been published; several more in the same hand and probably from the same scroll remain unpublished, as well as several fragments from wisdom instructions in the same hand that are likely to constitute the maxims of Ahiqar in demotic Egyptian form. The unpublished fragments of narrative passages as well as the by-far largest fragment of the instructions (P.Berlin 15658) are nowadays at Berlin, and smaller fragments of the wisdom sayings are at Vienna. ${ }^{6}$ The provenance is not certain, but from the style of the hand it is likely to be Soknopaiou Nesos.

1. There exists a very small fragment of certainly literary (probably narrative) nature now in Berlin (P.Berlin 23504); see Jasnow (1992: 40 n. 63).

2. I have argued on this line in several cases (Quack 2005a). For the early history of demotic literature, see further Hoffmann (2009).

3. Last, see Lindenberger 1985; Kottsieper 1991; Porten and Yardeni 1993: 23-53; Contini 2005; Niehr 2007; Weigl 2010. The relative position of the individual fragments can now be assured by the traces of the tax account that was first written in the scroll.

4. The standard edition still remains Conybeare, Harris, and Lewis (1913); for a more recent treatment, see Contini and Grottanelli (2005); and the overview of the textual history in Bricquel-Chatonnet (2005).

5. Zauzich (1976); Betrò (2005). See further Küchler (1979: 333-37), where also translations of some excerpts of the wisdom sayings (based on a provisional translation by Zauzich) are given; Ryholt (2004: 497-99).

6. Berlin: Relevant numbers of fragments possibly belonging to Ahiqar are P.Berlin 23730, 23829, 23830, and 23831. Vienna: Actually under P.Vienna Aeg numbers 6332 and 6659 . 
In order to give an objective impression of the factual basis, I will present the two published fragments of the narrative section in English translation, regardless of their bad preservation.

(a) Fragment Cairo ${ }^{7}$

$\mathrm{x}+1 \ldots] \operatorname{Egypt}(?)^{8}[\ldots$

$x+2 \ldots]^{9}$ the father $[\ldots$

$x+3 \ldots]$ all $[\ldots]$ which they $[\ldots$

$x+4 \ldots]$ misery $\ldots[\ldots$

$x+5 \ldots]$ whom(?) $?^{10} \mathrm{I}$ will give you a palm-branch(?) [ $\ldots$

$x+6 \ldots]$ the $\ldots$ which is mentioned above totally, ${ }^{11}$ so that it happens that she $[\ldots$

$x+7 \ldots]$. council among them(?). ${ }^{12}$ They said: "Let $[\ldots]$ give $[\ldots$

$x+8 \ldots]$ we $[\ldots]$, we failed, we were stupid .[...

$\mathrm{x}+9 \ldots$. the army which had rebelled is it which has gone to $\mathrm{Ni}[\text { niveh(? })^{13}$

$x+10 \ldots]$ in it $[\ldots]$ He found Akhiqar at the place $[\ldots$

$\mathrm{x}+11 \ldots]$. Go away to your districts ${ }^{14}$ and your ${ }^{15} \mathrm{c}[\mathrm{ities}(?) \ldots$

$x+12 \ldots]$. to the army which the chief Akhiq[ar ...

$x+13 \ldots$ thou $]$ ght about the evil thing which had happened [...

7. Original publication by Sobhy (1930: pl. VII, 2: without closer study), identified as a fragment of the Ahiqar tradition by Spiegelberg (1930). Philological edition by Zauzich (1976: 182-83).

8. Reading not secure, unfortunately. Read as ... nti by Zauzich, but in spite of the damage to the papyrus, the best visible sign seems to be rather an $m$ with a horizontal line above. I propose to read ' Kmy'.

9. According to the determinative, a foreign name.

10. I would read $n[m] e$ rather than $n t m$, "agreeable," proposed by Zauzich. Betrò (2005: 188 note b) has already argued correctly that the word nç̌m, "agreeable," is written differently in the P.Berlin 15658 , but her own reading $n m h$ fails to convince me.

11. I read only č̣ $r=f$ where Zauzich had proposed $t r=s i w g m=f$. Similarly complicated groups for $\stackrel{r}{r}$ are attested also in other manuscripts from Soknopaiou Nesos; see, e.g., the form in P.Vienna 12006 recto (Stadler 2004: 329).

12. I propose $i w t=w$ instead of Zauzich's $n 3 . w s m=w$; see the somewhat similar form in P.Vienna D. 12006 recto (Stadler 2004: 281).

13. The alternative translation "N[adin] came" proposed by Betrò (2005: 188-89 note $\mathrm{f}$ ) is excluded by the word order that would have to be i:iri $N[.$.$] iyi, not i:iri iy i$ $N[$. .].

14. I propose to read $n 3 y=\operatorname{tn} t \bar{s}$. [w], as is already held to be possible by Zauzich.

15 . The $n=t n$ is likely to be an unetymological writing for $n 3 y=t n$. I suppose that the formulation was analogous to, e.g., P.Krall 8, 18 and even more 9, 21. The traces at the end of the line would fit with the form of tmy, "city," attested in line $x+3$ of the Berlin fragment. 
(b) Fragment Berlin (P.23729), column $1^{16}$

$\mathrm{x}+1 \ldots$ a man 1$] \mathrm{ike}^{17}$ my father ...

$x+2 \ldots$ which] you have sought for us. You have not sought sorrow ${ }^{18}$

$x+3 \ldots]$ out of one city or the other, $[\ldots] \ldots$

$x+4 \ldots]$ chief. Nobody on earth could discover what happened to him.

$x+5 \ldots]$ man like Akhiqar who has

$\mathrm{x}+6 \ldots.]^{19}$ hastened to the place where Akhiqar

$x+7 \ldots]$ all $[\ldots]$. Hasten to the chief when he seeks

$x+8 \ldots$.$] the Assyrian ......$

$x+9 \ldots]$ to her $[\ldots]$

In spite of the very unsatisfactory state of preservation, we can make some guesses about the original setting. As already proposed by Zauzich (1976) and Betrò (2005: 178), they would fit very well with the situation when Assyria was challenged by the king of Egypt to a duel of riddles, and the Assyrian king was looking for a competent advisor to deal with them. Alternatively, Ryholt (2004: 498-99) has brought forth the (equally possible) proposal that they are from the section where Ahiqar was tricked into seemingly revolting against the king and where he was saved from execution. It is of some importance for my further discussion that the sections about the duel of riddles are not attested among the imperial Aramaic fragments from Elephantine, even though we cannot base too much on this fact, given that those fragments are only very partially preserved, with several pages being completely lost. ${ }^{20}$

I will go into fewer details about the fragments from the section of teachings because they are not yet published. At the outset, I should stress that the attribution of the wisdom fragments to a demotic Egyptian translation of Ahiqar cannot be strictly proven at the moment. An initial suspicion is based on the similarity of the hands, which points to the work of a single scribe for the wisdom fragments and for the narrative sections mentioning Ahiqar. Of course, one scribe could have

16. Edited by Zauzich (1976: 183-84). The pitiful fragments of column 2 do not merit a translation.

17. Here and in $x+5$, I would read $m$ c $y$ instead of the reading šc $y$ proposed by Zauzich; already Betrò (2005: 190 note a) admits that the sign is more likely to be $m$ than š. For the meaning, I take this to be a variant of the expression $m$ '; see Quack (1996).

18. Zauzichs reading $t h^{\varsigma}$ is clearly correct against the proposal $w^{\varsigma}$ ' by Betrò (2005: 190 note b).

19. According to the determinative, the name of a foreign person.

20. Porten and Yardeni (1993: 23). See Strugnell (1999), who argues for the originality of this episode, pointing out also that more leaves than only those with the tax-account could have been glued together. 
copied different manuscripts. There is even one noteworthy difference: all fragments of the narrative sections have an uninscribed verso, while the fragments with wisdom sayings have on the verso a hieratic copy of the Book of the Temple. ${ }^{21}$ But it would not be too surprising if only a portion of the verso was ever used for writing (Ryholt 2005: 27). In any case, one interesting formal aspect should be noted. In all of the later Ahiqar traditions, but not in the imperial Aramaic fragments, each saying is introduced in a rather dull way, with "my son." The demotic Egyptian fragments in question do not show any structuring of this sort, even though they contain several probable beginnings of new sayings.

Unfortunately, the incomplete preservation of phrases typically has a greater impact on the understandability of wisdom discourse than on a straight narrative; and in the actually known parts of the manuscript, there is hardly any complete sentence. Still, it seems useful to mention some phrases that were quoted by Küchler (1979: 336-37) from a preliminary translation by Zauzich because they served to support the idea that these were precepts how subjects should behave toward a prince. The problem is that in a large measure this interpretation seems due to an elementary misreading. What is really written as $p 3 y=k$ "your" was misread as $p 3$ wr "the prince." The remaining cases, mainly involving the word $h r i$, "chief, superior," are hardly characteristic for a prince and could as well refer to behavior within any hierarchical situation at the administrative level; as a matter of fact, advice for situations of this sort is quite common in Egyptian wisdom texts (Quack 1994: 152 and 184).

One specific passage certainly merits discussion because it goes some way toward establishing the attribution of the fragments to Ahiqar. We have the text "I have eaten gall" $(2, x+2)$ followed by a lacuna. In spite of the shortness, I can note that this is a fairly unusual formulation for a wisdom text. However, it has a very good attestation in the Ahiqar tradition (Nöldeke 1913: 41). Already, the Imperial Aramaic papyrus has a saying that Porten translates as "I have tasted the bitter medlar and the [taste] is strong but there is not (anything) which is more bitter than poverty," whereas Kottsieper understands it as "I have tasted the medlar and the gall, and the taste was strong, but there is not anything which is more bitter than poverty" (col. 6, 11 = Sachau pl. 45, 11) ${ }^{22}$ Lindenberger (1985: 501), on the basis of a slightly different restoration of a lacuna, even understands it as "I have tasted even the bitter medlar, and have eaten endives, but there is nothing more bitter than poverty."

21. For preliminary reports of this text see Quack (2000; 2004; 2005b; 2007).

22. Porten and Yardeni (1993: 36-37); similar also are Contini (2005: 123-24) and Niehr (2007: 43); see also Kottsieper (1990: 20) and the discussion of this saying by Yona (2007: 37-39); Weigl (2010: 157-60). 
These slight disagreements on the precise philological interpretation of the manuscript do not have any repercussions on its similarity with the demotic Egyptian phrase. Among the later Ahiqar traditions, one of the Syriac manuscripts has it as "I have eaten bitter things and swallowed viscous matter but I did not find anything more bitter than poverty" (Nau 1919: 153 and 159, saying 42). In the Slavonic version, we have "I have tasted gall and bitterness, and it was not more bitter than poverty"; in the Armenian we have "I have eaten endive and I have drunk gall, and it was not more bitter than poverty." The Arabic version has "I have eaten a colocynth, and swallowed aloes, and I have found nothing more bitter than poverty and scarcity" (Conybeare, Harris, and Lewis 1913 : 6 , saying $54 ; 32$, saying $69 ; 63$, saying $72 ; 136$, saying 40 ).

I will further mention one point that has been brought up previously (Quack 2002: 340; Betrò 2005: 180-81). There is one passage that invites a restoration in line with the later Syriac tradition. The preserved demotic text gives: "Do not love to gird ${ }^{23}$ to [ . . . ] occur. If beating ${ }^{24}[\ldots$. . ." It is at least tempting to restore the text as "Do not love to gird to s[trife! If strife occurs, beating will] occur. If beating [occurs, killing will occur]." This is, on the one hand, attested similarly as a saying in the Syriac Ahiqar tradition (but not in the preserved fragments of the imperial Aramaic version). There are slight differences in formulation. One manuscript has "Do not stand among those who quarrel. For from laughter there comes quarrel, and from quarrel there comes fighting, and from fighting comes killing" (Nau 1919: 154 and 159). Another has "Do not stand in the house of those who are on strife. For from a word there comes a quarrel, and from a quarrel is stirred up vexation, and from vexation comes killing." 25

On the other hand, we have a very similar formulation in another demotic Egyptian wisdom composition, namely, the Teachings of Khasheshonqy (normally but wrongly called "Onkhsheshonqy" in modern scholarship). ${ }^{26}$ There it runs as "Do not insult the common man. If insult occurs, beating will occur. If beating occurs, killing will occur" (22, 21-23). The Khasheshonqy saying has been connected with Ahiqar

23. Against the translation "amare la disputa" ( $m r$ mllh) of Betrò (2005: 180), it should be stressed that the orthography of the manuscript shows mri ml.

24. The reading hpr mby given by Betrò (2005: $180 \mathrm{n}$. 3) is in need of correction. The actual reading of the manuscript is $h p r$ in ${ }^{-} n 3^{\prime} . w$ mby [ . . ].

25. Conybeare, Harris, and Lewis (1913: 35 and 100, saying 8). For the ramifications of this motive from the third millennium B.C.E. onward, see Quack (1994: 215-17).

26. For the text, first edited by Glanville (1955), see Quack (2005a: 111-19); a complete German translation is Hoffmann and Quack (2007: 273-99, 365-68). 
already by Lichtheim (1983: 14-17), even without knowledge of the Papyrus Berlin 15658. I will take up the tricky question of the relation between Ahiqar and Khasheshonqy later on.

In summary, from what can be ascertained at the moment, the content of the demotic Egyptian fragments of Ahiqar is closer in content to the mainstream redaction of Ahiqar (as attested, e.g., in Syriac) than to the Imperial Aramaic version, a fact that entails complex questions of the actual history of redaction and transmission as well as the date of the demotic translation. Several quite-different possibilities rise up. First, the Egyptian version could be based on some later, considerably reworked version of Ahiqar. In that case, we would lose the relation to the Achaemenid period. The other option is that, in the early times, several quite-divergent versions of Ahiqar were in circulation, and the Egyptian translation is based on one that was rather different from the only preserved imperial Aramaic copy (from Elephantine) without necessarily being chronologically younger. ${ }^{27}$ One point in favor of this supposition is that the demotic fragments of the teachings, even if taking into account possible further advances in reading and understanding, are also certainly more different from the mainstream redaction of Ahigar than the ordinary divergences within that group (e.g., between the Syriac and the Armenian versions). Thus, I would propose to interpret the demotic Egyptian translation as testimony of a second free and "uncanonical" early redaction of Ahiqar, even if it is perhaps closer to the later Syriac version in some respects (especially the frame story) than to the Imperial Aramaic one. ${ }^{28}$

The options can perhaps be narrowed down a bit if we take the Greek Life of Aesop ${ }^{29}$ into consideration, because the sections it took over from the Ahiqar tradition (chaps. 101-23) already contain the narrative element of the riddle duel with the Egyptian king. Thus, it presupposes a state of the frame story similar to the Syriac tradition. The Greek text is normally considered to date from the Roman imperial time, even if

27. Fales (1994: 51-60) has stressed the differences between the Elephantine version and the later traditions, but his arguments have to be taken with caution, given the incomplete preservation of the Elephantine manuscript and especially the proof by Porten and Yardeni that several pages from it are completely lacking. See Bricquel-Chatonnet (2005: 28; 2007).

28. Unfortunately, the wisdom sayings published by Eshel et al. (2007) are too short and fragmentary to allow a judgment regarding whether they might be considered still another early uncanonical tradition of Ahiqar.

29. Edited by Perry (1962: 1-208); Papathomopoulos (1990). English translation in Daly (1961: 29-90); German translation by G. Poethke in Müller (1974); Italian translation of the section taken over from Ahigar by Grottanelli and Dettori (2005: 167-75). 
there has not been much in-depth discussion (Holzberg 2003). A fragment of a Greek papyrus from the late second or early third century C.E. (P.Berlin 11628) containing parts of the text provides a secure terminus ante quem. Besides, in its content it gives an additional terminus ante quem non. By naming the Egyptian king Nectanebo as the opponent in the duel of riddles, it cannot be earlier than his reign (360-342 в.C.E.). ${ }^{30}$

In any case, the rendering of the name of the Egyptian king is in favor of a milieu that was knowledgeable of Egypt (if not actually being in Egypt); ${ }^{31}$ a takeover directly from Aramaic without any Egyptian participation would have produced a more garbled rendering. To some degree, this might even bring up the question whether this particular section of the Life of Aesop was taken over from an Aramaic version of Ahiqar at all and not via the intermediary of a demotic Egyptian one. I cannot elaborate this point here, given its complexity and the fact that nobody up to now has ever explored a possibility such as this. But in Egypt during the Roman period, a demotic Egyptian text would have had a much wider circulation and thus been a more logical candidate for influence than an Aramaic one. ${ }^{32}$

Some evidence concerning the direction and sometimes even time of loans can be gained from the phonetic form of the names. The name of the protagonist appears as $3 \mathrm{hykl}$ or $3 \mathrm{hygl}$ in the demotic Egyptian version. With the laryngeal $h$, a form of this sort goes back to a Semitic prototype, excluding the possibility of a Greek intermediary. Besides, it should have come about at a time when the distinction between the two sounds $h$ and $h$ in Aramaic, although not indicated in the writing, was still maintained in speech. ${ }^{33}$ Furthermore, we have the development of an original Semitic velar $k$ to a demotic Egyptian $k$ or $g$. This spelling is typically used when an Egyptian sound was realized with a pronunciation like the Coptic 6 (Quack 2005c: 323-24). The sound shift from a $k$ to

30. Bricquel-Chatonnet (2006) has pointed out parallels for one episode of the riddle duel involving the construction of a castle in the air that would also indicate that this passage was known at least by the early third century C.E.

31. Already, Perry (1962: 2) has argued that the Greek Life of Aesop was composed by someone living in Egypt and adduced, besides the name of the king, also the important role of Isis as a helper of Aesop; Müller (1974: 8) also points out the role of strateges and nomarques, which are elements of the Hellenistic Egyptian administrative structure. I could add that in the episode of the whipped cat the Aesop romance (chap. 117) goes beyond any of the attested Ahiqar versions by making the (theologically correct) identification of the cat as sacred animal of the goddess of Bubastis.

32. The Jewish community in Egypt was largely using Greek as their language during this time.

33. On the date of the coalescence of the sounds, see, e.g., Beyer (1984: 101-11), who dates the coalescence of the two sounds to about the second century B.C.E. 
a 6 is quite regular for earlier loans from Semitic languages (Peust 1999: 107,109 a. 112-13; 307-10) but seems to have ceased at some time during the Late Period. Both points speak against a very late (i.e., Roman period) date of the Egyptian version. In principle, it is much more likely that an Aramaic text was taken over by the Egyptians at a time when Aramaic was relatively prominent by being an official administrative language. Thus, given the phonetic evidence as well as the inherent likelihood, I would still suppose an early, probably Achaemenid, date for the adoption of the Ahiqar text by the Egyptians.

One further issue must arise: in the mainstream redaction, Ahiqar regains the favor of the Assyrian king by being able to thwart an intrigue of the Egyptian king and triumphantly overcome the Egyptians in a duel of wisdom/trickery, bringing their tribute for three years back to Assyria. While there is a clear tradition of duels of sorcery in demotic Egyptian tales, e.g., in Setne II or the tale of Djoser and Imhotep against the Assyrians (Quack 2005a: 27 and 39-40), it is hard to imagine that the Egyptians would have liked a story telling of their own defeat, ${ }^{34}$ so we must ask whether they made some drastic alterations to the plotline to bring it into conformity with their own predilections. But one point to consider is that in the adaptation of this section within the Greek Life of Aesop, the Egyptian king is Nectanebo. This last king of the 30th Dynasty eventually lost his kingdom to the Persians. There is at least one demotic Egyptian narrative text dealing with him, the Dream of Nectanebo (Ryholt 2002; Quack 2005a: 64-65). Even though the end of that composition is not preserved, it can hardly have concluded with anything other than the downfall and flight of the king (perhaps coupled with a promise of return by one of his sons). It is possible that he was chosen by the Egyptians as the one under whom a defeat against superior foreign wisdom was an option.

To confound matters even further, some scholars have speculated about possible Egyptian influences in the Story of Ahiqar. Already, Dalley (2001: 155) had seen a mixing of Egyptian and Akkadian literary elements in the text. Her main point was that the narrative was autobiographical and thus in a genre much en vogue in Egypt. She pointed out the Tale of Wenamun, in which, according to her, this became a literary form. By contrast, in Mesopotamia functionaries were not used to writing autobiographical texts, and thus there are no literary predecessors for Ahiqar in this respect. ${ }^{35}$ I must admit that I do not feel

34. It took conversion to Christianity to have Egyptians take pleasure in the drowning of Pharaoh and his army in the Red Sea (Heinen 2007: 203-4).

35. The question of autobiographies in Akkadian texts was also taken up by Fales (1993: 144), who used its absence in cuneiform texts as one argument against 
very confident about an argument such as this. First, our knowledge of literary traditions in Northwest Semitic languages for the first millennium B.C.E. is so limited that ideas about what is "unusual" and thus in need of explanation by foreign influences are quite risky; and there actually seems to be sufficient evidence that, in first millennium Syria, high-ranking persons other than the king could also use the format of first-person biographies (Niehr 2007: 12). Second, even in Egypt it is far from normal to have a first-person narrative in a literary tale. Wenamun (using the outward form of an administrative report, not an autobiography!) is as much an exception in this as the Middle Egyptian Tale of Sinuhe (using the outward form of a funerary autobiography). All tales from Egypt attested during the first millennium B.C.E. are third-person narratives.

Besides, even for a wisdom text Ahiqar would not quite conform to an Egyptian model. Whereas it is normal to give a specific name and situation to a wisdom teacher in Egyptian teachings (as well as in Near Eastern texts), ${ }^{36}$ and within the teaching he can speak in the first person, ${ }^{37}$ there is no single attestation that the frame story is couched as an autobiography. Normally, an Egyptian wisdom text does not have a long narrative introduction, and the best case in which it does have one (the Teachings of Khasheshonqy) is stylized in the third person. So I am reluctant to see in this formal trait any evidence of Egyptian influence.

Others, especially Betrò (2000: 28-31; 2005: 184-87) and Contini and Grottanelli (2005: 84-88), have also pointed out specific motives in the narrative that they saw as Egyptian and proposed that the Story of Ahiqar gained its standard form in Egypt. I must admit that the elements they have brought up fail to convince me, because they tend to be too unspecific. The feigned death of Ahiqar is compared to the Late Egyptian Story of Truth and Falsehood. For the rehabilitation of a courtier, the Middle Egyptian Tale of Sinuhe is invoked. The riddle duel between kings is seen as similar to an episode in the demotic Tale of Setne II, as well as an episode reported by Plutarch, Banquet of Seven Sages about a duel between Amasis and an Ethiopian king. The motive of an impossi-

the theory of Luzzatto (1992), who had argued for an Akkadian original text; effort at defending her theory in Luzzatto (1994).

36. For the Near East, see the Sumerian Instruction of Shuruppak and the Teachings of Shupeawilim; see the editions in Alster (1974), and Kämmerer (1998). The ideas of Bergman (1979: 99) about specific Egyptian reasons for giving a name to the teacher are hardly pertinent.

37. The best case for this is the instruction preserved in P.Insinger with isolated instances of the first person within the text as well as a long "negative confession" in the first person at the beginning and the end of the text (Quack 2005a: 99 and 104). 
ble challenge countered with an even more impossible one is also found in the Late Egyptian Story of Apophis and Seqenenre. Concerning helping birds, the demotic Tale of Hi Hor is invoked. The punishment of the calumniator can be found also in the Late Egyptian Tale of Two Brothers (P.d'Orbiney). In all cases, the similarities remain in a very broad and unspecific way. It should not be difficult to point out equally similar ideas in many other cultures, and it would be bad methodology to base any conclusions about literary contacts on them.

Besides the direct translation, there is also the much-debated question of possible influence of Ahiqar on other Egyptian wisdom texts, especially the Teachings of Khasheshonqy. Some similarities between sayings in the texts have been interpreted, especially by Lichtheim (1983: 13-21), as proof of actual influence. She singled out about eight or nine sayings in the Khasheshonqy text that seemed, to her, to indicate that the demotic Egyptian composition was dependent on the Aramaic one. Nowadays, opinions are still divided among Egyptologists (Houser Wegner 2001: 81-92 and 191-208). I have already mentioned one case above because it was likely to be present also in the demotic translation of Ahiqar. Of the other cases, the one with the closest correspondence in wording is the saying "Better is small wealth gathered than large wealth scattered" (Khasheshonqy 23, 9). In the Syriac Ahiqar text, this can be found in a formulation that is normally translated as "better is poverty that gathers than wealth that scatters" (Lichtheim 1983: 18; Conybeare, Harris, and Lewis 1913: 107 and Syr. *45, saying 51). But as far as I see, there is no cogent reason why the participles of the Syriac text must be considered active voice. ${ }^{38}$ Thus, a translation "Better is a poverty that is gathered than large wealth that is scattered" seems possible for the Ahiqar text as well. Furthermore, also the demotic Egyptian text is amenable to two different interpretations, given that the writing of the verbal forms could intend the infinitive (with active meaning) as well as the qualitative (with passive meaning; the one that has been preferred up to now). In any case, complete agreement between Ahiqar and Khasheshonqy is attainable.

Equally good is the correspondence between "Do not prefer one of your children to another; you do not know which of them will be kind to you" (Khasheshonqy 13,11) and "Treat not your slave better than his fellow for you know not which of them you will need in the end" (Lichtheim 1983: 18-19; Conybeare, Harris, and Lewis 1913: 106 and Syr. ${ }^{*} 43$

38. See Nöldeke (1898: 104-5). Because the Syriac text as edited by Conybeare, Harris, and Lewis (1913: Syr. $\left.{ }^{*} 45\right)$ as well as Nau (1919: 154) does not have any indication of vowels, the difference between active and passive would not show in writing. 
saying 34), especially considering that the Ahiqar tradition of this saying has some fluctuation between "child" and "slave." A relatively close similarity in formulation can also be found between "You may trip over your foot in the house of a great man, you should not trip over your tongue" (Khasheshonqy 10, 7) and "Release not your word from your mouth until it is examined in your heart; for it is better for a man to trip with his foot than to trip with his tongue" (Ahiqar P.Berlin 165, no. 54) (39 $^{39}$ with many variants within the Ahiqar tradition (Lichtheim 1983: 19; Conybeare, Harris, and Lewis 1913: 107 and Syr. ${ }^{*} 46$ saying 53). I will refrain from discussing the cases of more broad similarity in conception. Here also, if the connection holds true, the relation to the later Syriac and other traditions would be much more obvious than to the Imperial Aramaic copy. ${ }^{40}$ Compared to the total amount of text in the composition, the number of direct parallels is rather small, although this comes hardly as a great surprise. ${ }^{41}$

Houser Wegner (2001: 195-208) has tried to disprove Lichtheim's conclusions by pointing out that the concepts in the cases in question can be illustrated in other Egyptian texts. In my opinion, an argument such as this is insufficient. Even if the concept in itself is not unattested elsewhere in Egyptian literature, the fact of the closely similar formulation in Khasheshonqy and Ahiqar should be explained, and there is nothing inherently implausible in using formulations found in foreign texts to illustrate concepts that as such are also at home in Egypt-it would even make more sense to take over ideas that are compatible with Egyptian traditions than totally strange ideas. For me, the similarity in the specific formulation is still a plausible indication that Khasheshonqy has taken over some sayings of Ahiqar, even if they do not amount to a dominating influence in his work. Future discoveries concerning the demotic translation of Ahigar might help to gain more clarity in this area. Provisionally, we can again note that here some version of Ahiqar was available that was nearer to the later versions than to the Elephantine manuscript. To evaluate this fact, it would be useful to fix the date of the demotic Egyptian Teachings of Khasheshonqy. Unfortunately, there

39. Nau (1919: 154 and 159 [no. 54]). This manuscript, giving "foot," is closest to the demotic Egyptian text. Other Syriac manuscripts have "heart"; see Nöldeke (1913: 42), who has already seen the superiority of this version even without knowledge of the Egyptian text.

40. Houser Wegner (2001: 192) adduces this fact as a problem for Lichtheim's analysis.

41. Thus, this fact cannot be used, contra Houser Wegner (2001: 194), as an argument against Lichtheim. See, e.g., Quack (1994: 194-205), in which even for innerEgyptian dependencies, the number of close parallels is usually quite limited. 
are some problems in this. While small fragmentary manuscripts containing sayings paralleled by the main manuscript of Khasheshonqy are attested beginning in the early Ptolemaic time (Quack 2005a: 111), the main manuscript itself is late Ptolemaic. The parallels themselves bear withess to a very fluctuating, unstable state concerning the sequence (and probably also number) of individual sayings. Thus, the sayings section of Khasheshongy is so much an "open" text that any single date for its composition is hardly meaningful, and the frame story is also attested in a reworked second manuscript (Ryholt 2000). While I myself have presented arguments for why the original composition of the text should be dated to the late Saïtic or Persian time (Quack 2002: 336-42), this can in no way be used as a fixed term for all of its individual sayings, and thus the date when sayings from the Ahiqar tradition were taken up in an Egyptian wisdom text remains open-but at least there are no cogent arguments against an early date. ${ }^{42}$

Besides similarities in some sayings, the general situation of the frame-story with an incarcerated sage has been compared (Betrò 2000: $29)$, even though there are obvious differences in the details. For memory, I will recapitulate the main points of the Egyptian text: A priest called Khasheshonqy, himself living in rather humble and unsatisfactory conditions, is visiting his old friend Ramose, who has made a great career and become chief physician of the Pharaoh. But he becomes involved in a murderous complot against the king. Khasheshonqy tries to dissuade him from this, but to no avail. Because one member of the royal bodyguard overhears them, the conspiracy is revealed and thwarted by the king. Ramose is condemned to death. Khasheshonqy, because he did not warn the king, is placed in prison in a fortress, without hope of amnesty. In this situation, he writes teachings on ostraca in order to instruct his son, whom he cannot teach personally.

While there are some slight, general resemblances to the Story of Ahiqar, we should not overlook the deep-seated differences. Ahiqar is not condemned to prison but sentenced to death (and only saved by a trick); and even though his hiding place might be as tight as a prison cell, it is functionally different. Khasheshonqy, in contrast to Ahiqar, is never pardoned or rehabilitated. Ahiqar delivers his teachings not in written form and at a distance but directly to his nephew Nadin. Ahiqar is completely blameless and only tricked into a situation where he seems to be a rebel, whereas Khasheshonqy's guilt in not denouncing

42. Lichtheim's (1983: 24-28) efforts at a later dating are mainly based on her supposition of an influence of Greek Gnomologia on the text, but there I fail to see convincing proof. 
a conspiracy is real. If there is any influence of one text on the other, it can only have been very distant and mitigated.

Perhaps more intriguing is a Greek-language papyrus fragment with a hero called Tinuphis, who is hidden in connection with a feigned execution (Haslam 1991; Quack 2005a: 121). It has been proposed by Kussl (1992) to reconstruct the fragmentary text in a way similar to an episode of the Aesop tradition, which in turn for this episode is based on the Ahiqar tradition. To make matters even more complicated, the name of Tinuphis is the same as that of the father of Khasheshonqy indicated in the frame story to the Egyptian instruction; and it is not one of the most frequent Egyptian names at that time. ${ }^{43}$ Thus, we possibly have a narrative motif that is very similar to the Story of Ahiqar but with an Egyptian setting. This can be seen as an indication that the frame story of Ahiqar was known in some form in Roman Egypt; and thus it confirms the direct evidence of the demotic translation (where this section is not preserved).

I feel much less confident concerning a relation proposed recently by Betrò (2000) and accepted by Contini and Grottanelli (2005: 80-84) between the frame story of Ahiqar and a fragmentary Egyptian tale transmitted on a jar of the Roman period. To some degree, this is based on a supposed similarity of the name of the Egyptian hero, understood as Hihor-which could be understood as an effort in an Egyptian pseudoetymology for the actual name of Ahiqar, especially because " $\mathrm{Hi}^{\prime}$ does not have a meaning as a formative part of an Egyptian name. However, the orthography of the text $\mathrm{t}^{44}$ permits the reading " $\mathrm{Hi}$, son of Hor," and a close parallel to the composition in another demotic text has the hero as "Henu, son of Hor" (with a clear orthography for "son");4 thus, the supposed similarity in name may be an illusion- " $\mathrm{Hi}$ " as a short form of a name is attested in Egypt (Ranke 1935: 233, no. 18). The content of the Egyptian tale shows a wise magician incarcerated at Elephantine. He sends out two birds that carry scrolls to the royal court, where they drop them-probably to inform the king of his problematic situation and to justify him against unjust accusations. There might be

43. Ranke (1935: 387, 9-10, and 388, 13) gives a few examples. Lüddeckens and Thissen (2000: 1350) has 11 written forms (including the literary attestation in the wisdom of Khasheshonqy), of which 3 are from the same papyrus referring to one person, and perhaps example no. 2 (Theban, father of a witness called ç̣t-hrr) also refers to the same person as those three examples (all about the possession rights for a Theban tomb of $\breve{c t}-h r$ r, son of $\breve{c} 3 i-n f r)$.

44. See Spiegelberg (1912: 29, no. 30) for another case on this jar in which the filiation sign is not written out.

45. P.Heidelberg 736 recto; edited by Spiegelberg (1917); see Quack (2005a: 78). 
some broad similarities to the theme of Ahiqar, but they are far from close and convincing: Ahiqar is not imprisoned but sentenced to death, and birds or scrolls do not play any role in his rehabilitation (even if trained eagles carrying boys are used by him in the riddle duel with the Egyptian king).

Another Aramaic fragment, unfortunately of uncertain origin (Porten and Yardeni 1993: 54-57; Porten 2004), contains part of a story with Hor son of Pwenesh as the hero. While it is long known that there are demotic Egyptian papyrus fragments from the Roman time showing the same hero (Zauzich 1978: 36), they have not yet been published; thus, a closer discussion is hardly possible. At least we can see that the text is about the adventures of a magician, which is a well-attested Egyptian literary motif. With some likelihood, however, the hero can be identified also with a certain Horus, son of Pneshe, attested as a master magician within the second Setne story (Quack 2005a: 40 and 62; Vittmann 2006: 583). We can suppose that a case of translation or at least free adaptation is involved. Given the clearly Egyptian setting with names and places, the direction of the borrowing is not in doubt; and this can provide an additional supporting argument concerning the problems with the date of the Egyptian Ahiqar tradition: even while direct evidence from pre-Roman time is lacking for the Egyptian side, the Aramaic documentation makes it clear that the Egyptian elements were already present in the Achaemenid time.

The verso of that same papyrus contains a prophetic text giving dire prognoses of lawlessness and social upheaval. While there is no obvious indication that it belongs to the same story as the recto text (and indeed, that can be considered highly unlikely), ${ }^{46}$ it is also, from the details it mentions (e.g., the city of Tanis), set in Egypt and possibly a translation from an Egyptian text. Given its relatively early date, it might have some bearing on the early history of compositions such as the so-called Lamb of Bokchoris (preserved in a papyrus from the time of Augustus), which I have argued on internal reasons goes back to an early (Saïtic) prototype modified in later times (Quack forthcoming b).

In a funerary cave near Sheikh Fadl, there is preserved a long narrative written in ink on panels of the wall (Lemaire 1995; Porten and Yardeni 1999: 286-98; Holm 2007). While there is no preserved direct parallel in the Egyptian documentation, the main characters have

46. Porten (2004: 452-53) has speculated to which degree the appearance of the texts on two sides of one papyrus might be not coincidental. Given my experience with Egyptian papyri written on both sides with literary texts, I would say that the likelihood of a close internal relationship is not very high, even if the two texts are likely to have been used in the same milieu. 
Egyptian names and the action is set in Egypt. Mentioning the kings Taharqa and Nekho, as well as the hero Inaros, ${ }^{47}$ this composition is likely to be based on an Egyptian model and set at about the middle of the 7th century B.C.E. Inaros is well known as main figure in a cycle of tales (Quack 2005a: 44-61), and there is even some possibility that the ongoing work of reconstructing the Inaros epic might turn up some positive proof for the relation between the Aramaic text and the Egyptian composition.

Besides the translations, we have also the more curious case of phonetic renderings in the other script. This also went in both directions. There is an Aramaic leather fragment at Berlin coming from Elephantine (Porten and Yardeni 1999: 137) that Vittmann (2003: 118-19) has convincingly identified as Egyptian language (Quack 2004b). It seems to contain invocations to deities of Elephantine and mentions Philae. Unfortunately, the fragment is small, with no single complete line, and a good part of the text is still not clearly understood.

Even more challenging, and going in the opposite direction, is the famous papyrus Amherst 63, written in demotic script but Aramaic language and containing, inter alia, the well-known "paganized" version of Psalm 20 as well as the tale of Ashurbanipal and Shamash-Shumukin. ${ }^{48}$

These two cases as well as a possible but less-certain case involving a spell against scorpions written in demotic Egyptian but linguistically perhaps Aramaic ${ }^{49}$ bring up the question of local communities whose linguistic affiliation was no longer coeval with their graphic one. Especially for the very long Papyrus Amherst 63 (about 23 columns preserved), it has to be stressed that its dimensions go far beyond the usual case of short spells (only a few lines) transmitted in Egyptian script and foreign language in other cases, mostly from the New Kingdom (Quack 2010). The interpretation of compositions of this sort must first deal with a basic distinction: were these texts used as carriers of semantic information in the conventional sense, that is, as making statements about gods, history, and so on, or were they carriers purely of phonetic information containing a power of recitation regardless of what they actually said and potentially used by people without seman-

47. For the reading of the name, I follow Lemaire (1995) and Vittmann (2003: 104-5). Porten and Yardeni (1999: 290) read Snhrw.

48. Among the many publications on this text, I will mention only Nims and Steiner (1983); Steiner and Nims (1984, 1985); Steiner (1991, 1995); Vleeming and Wesselius (1982, 1983-84, 1985, 1990); Kottsieper (1988, 1997); and Rösel (2000). Preliminary translation of the whole text by R. C. Steiner are in Hallo (1997: 309-27).

49. Proposed mainly by Steiner (2001), with a slightly reserved reaction in Vittmann (2003: 119). 
tic understanding of the text? The second solution would be easier to understand, because then only the legibility of the writing would be important for the user. We could imagine, for example, an Aramaicspeaking person at Elephantine making use of what he knew to be a powerful spell of protection without bothering very much with the finer linguistic details of the spell, as long as he could read it in his own Aramaic script. Or the script could be a question of identity for him even if he knew the foreign language - there would be modern parallels such as, for example, Turkish written in Greek script or German written in Hebrew script. If an Aramaic-speaking user of the Aramaic leather fragment understood the semantics of the text, we would of course have to ask to what degree he can be understood as a Jew, given the number of Egyptian deities invoked in the text, even if there are some attestations of a coexistence of the Jewish god and the indigenous Egyptian gods, as in one greeting formula, "I have blessed you by Jaho and Khnum," on an Aramaic ostracon from Elephantine (Porten and Yardeni 1999: 172 no. D7.21).

The main problem for an interpretation such as this is of course Papyrus Amherst 63, which is way too long to be a normal case of recitation literature; and besides, the story of Ashurbanipal and Shamash-Shumukin is not even a recitation genre. ${ }^{50}$ But the obvious Near Eastern affiliation of the content would make it equally strange to think of the demotic Egyptian script as a marker of cultural identity. And while the number of groups actually used in the text is limited enough to make the writing system not much more difficult to learn than ordinary Aramaic writing, it has the drawback of not clearly differentiating between voiced, voiceless, and emphatic consonants, a distinction fundamental for Semitic languages. Thus, the writing system is hardly an objective advantage in making the text easier to understand. I must confess that I still lack a cogent explanation for the choice of the writing system in this case, but at least it evidently shows the cultural imprint of Egypt on the users of the text.

Concerning those users, one important question must be asked: were they Jews or influenced by Jewish traditions? On the one hand, one of the texts of the papyrus is a variant form of the text known as Psalm 20; thus, a Jewish background looks convincing. However, I would not give too much credit to argumentation such as this. The text could have circulated in the Levantine/Syriac region quite independently of the specific religious affiliation because as a prayer for protection it would

50. Still, it should be noted that Steiner (1991: 362-63) considers the text to be liturgical. 
fill a demand while not containing religious specialties that would limit its usability to one single religious group. On the other hand, we have to face the thorny question of who one deity invoked in the text actually is. The original idea that it was the Egyptian god Horus ${ }^{51}$ has by now been laid to rest for good. There has been a theory that the word in question should be understood as a rendering of Yahwe, ${ }^{52}$ while another understood it as El. The last solution, favored mainly by Kottsieper (1988: 224-27; 1997: 54-55), would leave many possible religious affiliations, but in my opinion, it is excluded by the actual writing. ${ }^{53}$ The second one, proposed by Zauzich and endorsed with slight modifications by Rösel (2000: 93-94), would point to a specifically Jewish identity, but in my opinion it is equally excluded by the actual writing. ${ }^{54}$ This specific deity, however, seems only addressed within a rather short section of the text (mainly cols. 12 and 13 in the numbering of Wesselius and Vleeming), whereas otherwise Mar or Adonai for "lord/my lord" are the most frequent words.

Even though there is no direct attestation from the Achaemenid period, it seems useful to bring up also the question of the relation of a section in the Wisdom of Jesus Ben Sira to passages of the Satire of the Trades (Jäger 2004: 305-17). In that section, different craftsmen professions are derided, often with striking similarities in formulation. Because there is no certain attestation from Egypt that classical Middle Egyptian compositions continued to be copied during the Ptolemaic and Roman periods, we must, if we accept the influence of the Egyptian text on the Jewish one, reckon with the possibility that there was a (lost) intermediary dating from the Saitic or Persian period, where either the Middle Egyptian composition was adapted in demotic Egyptian or (less likely) directly taken over into a Semitic language. This problem should be tackled in connection with the currently controversial thesis of re-

51. Nims and Steiner (1983: 265); still used in Zevit (1990: 217-18).

52. Zauzich (1985). Tentatively accepted by Vleeming and Wesselius (1985: 3942), even while they point out some problems.

53. Some arguments are already brought forth by Zauzich apud Rösel (2000: 92 n. 82). Additionally, it has to be said that the demotic writing of the preposition $r$ before a suffix always uses $r$ or $i$ as the first element, never 3 .

54. While an original Egyptian 3 could develop into a $y$, the demotic writing system always handles these cases phonetically, i.e., it actually has $y$, while a demotic writing with the one-consonantal sign 3 never stands for a phonetic $y$. The preposition $h r$ as a writing for the consonant $h$ would be most surprising in a text from the fourth century B.C.E. Erichsen (1954: 322), to whom Zauzich refers for the use of $h r$ for $h$, is based on a misunderstanding; what we have there is a specific paleographic form of $h$ attested in some Fayyumic manuscripts from the Roman period (and even there it is quite different from the form of $h r$ ). 
lations between Ben Sira and the demotic Egyptian wisdom text best preserved in Papyrus Insinger. ${ }^{55}$ While some similarities in formulation are evident, the direction of any contacts was in doubt due to discussions about the date of the Egyptian text. The Ben Sira composition is safely anchored in the second century B.C.E. due to the exact dates given in the colophon and historical indications in the text itself, but for the demotic Egyptian wisdom book, we are on less-safe ground. The attested manuscripts are all younger than Ben Sira, none of them going back before the first century B.C.E. But the date of the original text is quite a different matter. I have argued elsewhere from language and writing, as well as content, that we should reckon with a rather early, probably Saïtic original (Quack 2002: 332-36). Thus, if there really are cases in which the formulation has specific similarities, we should better suppose that the Egyptian side was the lender.

In summary, the contact between Aramaic and Egyptian literature must have been quite intense. There is hardly any Aramaic literary fragment from the Achaemenid period from Egypt (except the copy of the Behistun inscription) that is not, in one or the other direction, relevant for contacts or even direct translations. We must ask for the reasons, especially because this phenomenon is rather distinct from the Greco-Roman period when there was translation of literary (mainly religious) texts from Egyptian into Greek (Quack 2003b: 330-32), but on a comparatively smaller scale and more unidirectional. While we do have translations from Egyptian into Greek, the opposite case is attested for administrative texts but not for literature. ${ }^{56}$

One possible reason could be the different status of the respective languages and communities. The Greeks became the rulers of Egypt, and for prestige literature, the Greek literary and philosophical tradition was highly relevant. This led to a bilingual situation in which the indigenous elites learned Greek and read these texts in their original language. On the contrary, the Jews (and other Aramaic-speaking groups) were one of many subject people groups of the Persian Empire, and their literature did not have any particular status, in spite of the fact that their language and writing was the official medium of imperial administrative communication.

55. Lichtheim (1983: 122-87). Denied by Houser Wegner (2001: 245-61).

56. Administrative texts: There is one unpublished letter written in hieratic script but demotic language that indicates explicitly that it was translated from the Greek. Literature: This direction of translation only becomes relevant with Coptic literature, which is to a large degree a literature of translations from the Greek. 


\section{Bibliography}

Alster, B.

1974 The Instructions of Suruppak: A Sumerian Proverb Collection. Mesopotamia 2. Copenhagen: Akademisk Forlag.

Bergman, J.

1979 Gedanken zum Thema "Lehre-Testament-Grab-Name." Pp. 73-104 in Studien zu altägyptischen Lebenslehren, ed. E. Hornung and O. Keel. OBO 28. Freiburg: Universitätsverlag / Göttingen: Vandenhoeck \& Ruprecht.

Betrò, M. C.

2000 La storia del Mago Hi-Hor: Variazioni egiziane sul tema di Ahiqar. Pp. 23-35 in Donum Natalicum: Studi presentati a Claudio Saporetti in occasione del suo 60. Compleanno, ed. P. Negri Scafa and P. Gentili. Rome: Borgia.

2005 La tradizione di Achiqar in Egitto. Pp. 177-91 in Contini and Grottanelli 2005.

Beyer, $\mathrm{K}$.

1984 Die Aramäischen Texte vom Toten Meer samt den Inschriften aus Palästina, dem Testament Levis aus der Kairoer Genisa, der Fastenrolle und den alten talmudischen Zitaten: Aramaistische Einleitung, Text-Übersetzung-Deutung, Grammatik/Wörterbuch. Deutsch-aramäische Wortliste. Register. Göttingen: Vandenhoeck \& Ruprecht.

Bricquel-Chatonnet, $\mathrm{F}$.

2005 L'histoire et la sagesse d'Ahiqar: Fortune littéraire de la vie d'un dignitaire araméen à la cour assyrienne. Pp. $17-40$ in D'un orient l'autre: Actes des troisièmes journées de l'Orient Bordeaux, 2-4 octobre 2002, ed. J.-L. Bacqué-Grammont, A. Pino and S. Khoury. Leuven: Peeters.

2006 Construis-moi un château dans le ciel: Remarques sur un motif de conte, d'Ahiqar à Thomas. Harp 20: 55-64.

2007 De l'Ahiqar araméen à l'Ahiqar syriaque: Les voies de transmission d'un roman. Pp. 51-57 in Der christliche Orient und seine Umwelt, ed. S. G. Vashalomidze. Studies in Oriental Religions 56. Wiesbaden: Harrassowitz.

Bruyce, G. E.

1979: A Legacy of Wisdom: The Egyptian Contribution to the Wisdom of Israel. London: Bucknell University Press.

Conybeare, F. C.; Harris, J. R.; and Smith Lewis, A.

1913 The Story of Ahikar. Cambridge: Cambridge University Press.

Contini, R.

2005 Il testo aramaico di Elefantine. Pp. 113-39 in Contini and Grottanelli 2005.

Contini, R., and Grottanelli, C., eds.

2005 Il Saggio Ahiqar: Fortuna e trasformazioni di uno scritto sapienziali. Il testo più antico e le sue versioni. Brescia: Paideia. 
Dalley, S.

2001 Assyrian Court Narratives in Aramaic and Egyptian: Historical Fiction. Pp. 149-61 in Historiography in the Cuneiform World, Proceedings of the XVL $L^{e}$ Rencontre Assyriologique Internationale, Part I, ed. T. Abusch et al. Bethesda, MD: CDL.

Daly, L. W.

1961 Aesop without Morals: The Famous Fables, and a Life of Aesop. New York: Yoseloff.

Eshel, E.; Puech, E.; and Kloner, A.

2007 Aramaic Scribal Exercises of the Hellenistic Period from Maresha. BASOR 345: 39-62.

Erichsen, W.

1954 Demotisches Glossar. Copenhagen: Munksgaard.

Fales, F. M.

1993 Storia di Ahiqar tra Oriente e Grecia: La prospettiva dall'antico Oriente. Quaderni di Studia 38: 143-66.

1994 Riflessione sull'Ahiqar di Elephantine. Orientis antiqui miscellanea 1: 39-60.

Fox, M. V.

1985 The Song of Songs and the Ancient Egyptian Love Songs. Madison, WI: University of Wisconsin Press.

Glanville, S. R. K.

1955 Catalogue of Demotic Papyri in the British Museum, vol. 2: The Instructions of Onkhsheshonqi. London: British Museum.

Grottanelli, C., and Dettori, E.

2005 La Vita Aesopi. Pp. 167-75 in Contini and Grottanelli 2005.

Hallo, W. W., ed.

1997 The Context of Scripture, vol. 1: Canonical Compositions from the Biblical World. Leiden: Brill.

Haslam, M. W.

1991 Narrative about Tinouphis in Prosimetrum. Pp. 35-45 in Papyri Greek and Egyptian in Honour of Eric Gardner Turner. London: EES.

Heinen, $\mathrm{H}$.

2007 Ägypten im Römischen Reich. Bemerkungen zum Thema Akkulturation und Identität. Pp. 186-207 in Ägypten unter fremder Herrschaft zwischen persischer Satrapie und römischer Provinz, ed. S. Pfeiffer. Oikumene 3. Frankfurt: Verlag Antike.

Hoffmann, F.

2009 Die Entstehung der demotischen Erzählliteratur: Beobachtungen zum überlieferungsgeschichtlichen Kontext. Pp. 351-84 in Erzählen in frühen Hochkulturen, I. Der Fall Ägypten, ed. H. Roeder. Munich: Fink.

Hoffmann, F., and Quack, J. F.

2007. Anthologie der demotischen Literatur. Einführungen und Quellentexte zur Ägyptologie 4. Berlin: Lit Verlag. 
Holm, T. L.

2007 The Sheikh Faḍl Inscription in Its Literary and Historical Context. Aramaic Studies 5: 193-224.

Holzberg, N.

2003 Novel-like Works of Extended Prose Fiction II C. Fable: Aesop. Life of Aesop. Pp. 633-39 in The Novel in the Ancient World, ed. G. Schmeling. Rev. ed. Leiden: Brill.

Houser Wegner, J.

2001 Cultural and Literary Continuity in the Demotic Instructions. Ph.D. diss. Yale University.

Humbert, P.

1929 Recherches sur les sources égyptiennes de la littérature sapientale d'Israël. Neuchâtel: Sécretariat de l’Université.

Jäger, $\mathrm{S}$.

2004 Altägyptische Berufstypologien. LingAeg SM 4. Göttingen: Seminar für Ägyptologie und Koptologie.

Jasnow, R.

1992 A Late Period Hieratic Wisdom Text (P. Brooklyn 47.218.135). SAOC 52. Chicago: University of Chicago Press.

Kämmerer, T. R.

1998 Šimâ milka: Induktion und Reception der mittelbabylonischen Dichtung von Ugarit, Emar und Tell el-Amarna. Münster: Ugarit-Verlag.

Koch-Westenholz, U.

1995 Mesopotamian Astrology: An Introduction to Babylonian and Assyrian Celestial Divination. CNI Publications 19. Copenhagen: Museum Tusculanum.

Kottsieper, I.

1988 Anmerkungen zu Pap. Amherst 63, I. 12, 11-19: Eine aramäische Version von Psalm 20. ZAW 100: 217-44.

1990 Die Sprache der Ahiqarsprüche. BZAW 194. Berlin: de Gruyter.

1991 Die Geschichte und die Sprüche des Weisen Achiqar. Pp. 320-47 in TUAT 3/2.

1997 Anmerkungen zu Pap. Amherst 63. Teil II-IV. UF 29: 385-434.

Küchler, M.

1979 Frühjüdische Weisheitstraditionen: Zum Fortgang weisheitlichen Denkens im Bereich des frühjüdischen Jahweglaubens. OBO 26. Freiburg: Universitätsverlag / Göttingen: Vandenhoeck \& Ruprecht.

Kussl, R.

1992 Achikar, Tinuphis und Äsop. Pp. 23-30 in Der Äsop-Roman: Motivgeschichte und Erzählstruktur, ed. N. Holzberg. Tübingen: Narr.

Laisney, V.

2007 L'enseignement d'Aménémopé. Studia Pohl SM 19. Rome: Pontifical Biblical Institute. 
Lemaire, A.

1995 Les inscriptions araméennes de Cheikh-Fadl (Égypte). Pp. 77-132 in Studia Aramaica: New Sources and New Approaches, ed. M. Geller. JSS Supplement 4. Oxford: Oxford University Press.

Lichtheim, M.

1983 Late-Egyptian Wisdom Literature in the International Context: A Study of Demotic Instructions. OBO 52. Freiburg: Universitätsverlag / Göttingen: Vandenhoeck \& Ruprecht.

Lieven, A. von

2007 The Carlsberg Papyri 8: Grundriß des Laufes der Sterne. Das sogenannte Nutbuch. CNI Publications 31. Copenhagen: Museum Tusculanum.

Lindenberger, J. M.

1985 Ahiqar. Pp. 479-507 in The Old Testament Pseudepigrapha, ed. J. H. Charlesworth. Vol. 2. Garden City, NY: Doubleday.

Lüddeckens, E., and Thissen, H.-J.

2000 Demotisches Namenbuch. Vol. 1. Wiesbaden: Ludwig Reichert.

Luzzatto, M. J.

1992 Grecia e vicino Oriente: Trace della "Storia di Ahiqar" nella cultura greca tra VI e V secolo a.C. Quaderni di Studia 36: 5-84.

1994 Ancora sulla "Storia di Ahiqar." Quaderni di Studia 39: 253-77.

Müller, W., ed.

1974 Das Leben Äsops. Leipzig: Dieterich.

Nau, F.

1919 Histoire et sagesse d'Ahiqar d'après le manuscrit de Berlin «Sachau 162», fol. 86 sq. ROC 21: 148-60.

Niehr, $\mathrm{H}$.

2007 Aramäischer Ahiqar, Jüdische Schriften aus hellenistisch-römischer Zeit NF 2/2. Gütersloh: Gütersloher Verlag.

Nims, F., and Steiner, R. C.

1983 A Paganized Version of Psalm 20:2-6 from the Aramaic Text in Demotic Script. JAOS 103: 261-74.

Nöldeke, T.

1898 Kurzgefaßte Syrische Grammatik. Leipzig: Tauchnitz; repr. Darmstadt: Wissenschaftliche Buchgesellschaft, 1977.

1913 Untersuchungen zum Achiqar-Roman. Berlin: Weidmann.

Papathomopoulos, M.

1990 O bios tou Esopou: I paralagi G. Kritiki ekdosis me isagogii ke metafrasis. Ioannina: Panepistēmio Iōanninōn.

Parpola, S.

2005 Il retroterra assiro di Ahiqar. Pp. 91-112 in Contini and Grottanelli 2005.

Perry, B. E.

1962 Aesopica: A Series of Texts Relating to Aesop or Ascribed to Him or Closely Connected with the Literary Tradition That Bears His Name. Urbana: University of Illinois Press. 
Peust, C.

1999 Egyptian Phonology: An Introduction to the Phonology of a Dead Language. Göttingen: Peust \& Gutschmidt.

Porten, B.

2004 The Prophecy of Hor bar Punesh and the Demise of Righteousness: An Aramaic Papyrus in the British Library. Pp. 427-66 and pls.xxxvxxxvi in Res severa verum gaudium: Festschrift für Karl-Theodor Zauzich zum 65. Geburtstag am 8. Juni 2004, ed. F. Hoffmann and H. J. Thissen. StDe 6. Leuven: Peeters.

Porten, B., and Yardeni, A.

1993 Textbook of Aramaic Documents from Ancient Egypt. Vol. 3. Jerusalem: Hebrew University Press.

1999 Textbook of Aramaic Documents from Ancient Egypt. Vol. 4. Jerusalem: Hebrew University Press.

Quack, J. F.

1994 Die Lehren des Ani: Ein neuägyptischer Weisheitstext in seinem kulturellen Umfeld. OBO 141. Freiburg: Universitätsverlag / Göttingen: Vandenhoeck \& Ruprecht.

1996 ' $w$ "Größe" und " "Zustand, Art": Zwei verwechselbare demotische Wörter. Enchoria 23: 62-75.

2000 Das Buch vom Tempel und verwandte Texte: Ein Vorbericht. ARG 2: $1-20$.

2002 Zur Chronologie der demotischen Weisheitsliteratur. Pp. 329-42 in Acts of the Seventh International Conference of Demotic Studies, Copenhagen, 23-27 August 1999, ed. K. Ryholt. CNI Publications 27. Copenhagen: Museum Tusculanum.

2003a Aus einer spätzeitlichen literarischen Sammelhandschrift, ZÄS 130: $182-85$ and pl. xlv.

2003b „Ich bin Isis, Herrin der beiden Länder": Versuch zum demotischen Hintergrund der memphitischen Isisaretalogie. Pp. 319-65 in Egypt: Temple of the Whole World. Studies in Honour of Jan Assmann, ed. S. Meyer. Numen Book Series 97. Leiden: Brill.

2004a Organiser le culte idéal: Le Manuel du Temple Égyptien. BSFÉ 160: 9-25.

2004b Review of Vittmann 2003. JAOS 24: 360-61.

2005a Einführung in die altägyptische Literaturgeschichte III: Die demotische und gräko-ägyptische Literatur. Einführungen und Quellentexte zur Ägyptologie 3. Münster: LIT Verlag. (2nd ed., Münster: LIT Verlag, 2009).

2005b Die Überlieferungsstruktur des Buches vom Tempel. Pp. 105-15 in Tebtynis und Soknopaiou Nesos: Leben im römerzeitlichen Fajum, ed. S. Lippert, M. Schentuleit. Wiesbaden: Harrassowitz.

2005c Zu den vorarabischen semitischen Lehnwörtern des Koptischen. Pp. 307-38 in Studia semitica et Semitohamitica: Festschrift für Rainer Voigt anläßlich seines 60. Geburtstages am 17. Januar 2004, ed. B. Bur- 
tea, J. Tropper, and H. Younansardaroud. AOAT 317. Münster: Ugarit-Verlag.

2007 Die Götterliste des Buches vom Tempel und die gaü̈bergreifenden Dekorationsprogramme. Pp. 213-35 in 6. Ägyptologische Tempeltagung. Funktion und Gebrauch altägyptischer Tempelräume, Leiden 4.-7. September 2002, ed. B. Haring and A. Klug, Wiesbaden: Harrassowitz.

2010 Egyptian Writing for Non-Egyptian Languages and Vice-Versa: A Short Overview. Pp. 317-25 in The Idea of Writing: Play and Complexity, ed. A. de Voogt and I. Finkel. Leiden: Brill.

Forthcoming Ist der Meder an allem Schuld? Zur Frage des realhistorischen Hintergrundes der gräköägyptischen prophetischen Literatur. In Ägypten zwischen innerem Zwist und äußerem Druck: Die Zeit Ptolemaios' VI. bis VIII., ed. A. Järdens and J. Quack. Wiesbaden: Harrassowitz.

Ranke, $\mathrm{H}$.

1935 Die Ägyptischen Personennamen. Glückstadt: Augustin.

Römheld, D.

1989 Wege der Weisheit: Die Lehren Amenemopes und Proverbien 22,17-24,22. BZAW 184. Berlin: de Gruyter.

Rösel, M.

2000 Israels Psalmen in Ägypten? Papyrus Amherst 63 und die Psalmen XX und LXXV. Vetus Testamentum 50: 81-99.

Ryholt, K.

2000 A New Version of the Introduction to the Teaching of OnchSheshonqy (P. Carlsberg 304 + PSI Inv. D 5 + P. CtYBR 4512 + P. Berlin P. 30489). Pp. 113-40 and pls. 16-22 in The Carlsberg Papyri 3: A Miscellany of Demotic Texts and Studies, ed. P. J. Frandsen and K. Ryholt. CNI Publications 22. Copenhagen: Museum Tusculanum.

2002 Nectanebo's Dream or the Prophecy of Petesis. Pp. 212-41 in Apokalyptik und Ägypten: Eine kritische Analyse der relevanten Texte aus dem griechisch-römischen Ägypten, ed. A. Blasius, B. U. Schipper. OLA 107. Leuven: Peeters.

2004 The Assyrian Invasion of Egypt in Egyptian Literary Tradition: A Survey of the Narrative Source Material. Pp. 483-510 in Assyria and Beyond: Studies Presented to Mogens Trolle Larsen, ed. J. G. Dercksen. Leiden: Nederlands Instituut voor het Nabije Oosten.

2005 The Carlsberg Papyri 6: The Petese Stories II (P. Petese II). CNI Publications 29. Copenhagen: Museum Tusculanum.

Sobhy, G. P. G.

1930 Miscellanea. JEA 16: 3-5 and pls. iii-viii.

Spiegelberg, W.

1912 Demotische Texte auf Krügen. DemSt 5. Leipzig: Hinrichs.

1917 Der demotische Papyrus Heidelberg 736. ZÄS 53: 30-33 and pl. vii.

1930 Achikar in einem demotischen Texte der römischen Kaiserzeit. OLZ 33: 961. 
Stadler, M.

2004 Isis, das göttliche Kind und die Weltordnung: Neue religiöse Texte aus dem Fayum nach dem Papyrus Wien D. 12006 recto. MPER n.s. 23. Vienna: Hollinek.

Steiner, R. C.

1991 The Aramaic Text in Demotic Script: The Liturgy of a New Year's Festival Imported from Bethel to Syene by Exiles from Rash. JAOS 111: 362-63.

1995 Papyrus Amherst 63: A New Source for the Language, Literature, Religion and History of the Aramaens. Pp. 199-207 in Studia Aramaica: New Sources and New Approaches, ed. J. Geller. JSS Supplement 4. Oxford: Oxford University Press.

2001 The Scorpion Spell from Wadi Oammamat: Another Aramaic Text in Demotic Script. JNES 60: 259-68.

Steiner, R. C., and Nims, C. F.

1984 You Can't Offer Your Sacrifice and Eat It Too: A Polemical Poem from the Aramaic Text in Demotic Script. JNES 43: 89-114.

1985 Ashurbanipal and Shamash-shum-ukin: A Tale of Two Brothers from the Aramaic Text in Demotic Script. Revue Biblique 92: 60-81.

Strugnell, J.

1999 Problems in the Development of the Ahîqar Tale. Eretz-Israel 26 (Cross Volume): $204^{*}-11^{*}$.

Vittmann, G.

2003 Ägypten und die Fremden im ersten vorchristlichen Jahrhundert. Mainz: Zabern.

2006 Zwischen Integration und Ausgrenzung: Zur Akkulturation von Ausländern im spätzeitlichen Ägypten. Pp. 561-95 in Altertum und Mittelmeerraum: Die antike Welt diesseits und jenseits der Levante. Festschrift für Peter W. Haider zum 60. Geburtstag, ed. R. Rollinger and B. Truschnegg. Oriens et Occidens 12. Stuttgart: Steiner.

Vleeming, S. P., and Wesselius, J. W.

1982 An Aramaic Hymn from the Fourth Century B.C. BiOr 39: 501-9.

1983-84 Betel the Saviour. JEOL 28: 110-40.

1985 Studies in Papyrus Amherst 63: Essays on the Aramaic Texts in Aramaic/Demotic Papyrus Amherst 63. Vol. 1. Amsterdam: Juda Palache Instituut.

1990 Studies in Papyrus Amherst 63: Essays on the Aramaic Texts in Aramaic/Demotic Papyrus Amherst 63. Vol. 2. Amsterdam: Juda Palache Instituut.

Weigl, A.

2010 Die aramäische Achikar-Sprüche aus Elephantine und die alttestamentliche Weisheitliteratur. Berlin: de Gruyter.

Yona, S.

2007 Shared Stylistic Patterns in the Aramaic Proverbs of Ahiqar and Hebrew Wisdom. Ancient Near Eastern Studies 44: 29-49. 
Zauzich, K.-T.

1976 Demotische Fragmente zum Ahikar-Roman. Pp. 180-85 in Folia Rara Wolfgang Voigt LXV. diem natalem celebranti ab amicis et catalogorum codicum orientalium conscribendorum collegis dedicata. Wiesbaden: Steiner.

1978 Neue demotische literarische Texte in demotischer Schrift. Enchoria 8,2: 33-38.

1985 Der Gott des aramäisch-demotischen Papyrus Amherst 63. GM 85: 89-90.

Zevit, Z.

1990 The Common Origin of the Aramaicised Prayer to Horus and of Psalm 20. JAOS 110: 213-28. 